\title{
EFFECT OF SOME GROWTH RETARDANTS ON GROWTH AND FLOWERING OF HELIANTHUS ANNUUS L. CV. SUNRICH ORANGE SUMMER 981V PLANTS \\ B- APPLICATION OF ANCYMIDOL, DAMINOZIDE AND ETHEPHON IN COMBINATIONS
}

\author{
Azza M. Abdel-Moniem \\ Ornamental Plants and Landscape Gardening Res. Dept., Hort. Res. Inst., ARC, Giza, Egypt.
}

ABSTRACT: Pot experiments were carried out at the nursery of Hort. Res. Inst, Giza, Egypt throughout the two successive seasons of 2014 and 2015. The work embodied in this paper was to study the influence of some growth regulators (daminozide, ancymidol and ethephon) on sunflower (Helianthus annuus L. cv. Sunrich Orange Summer 981V) plant for achieving the hope of producing dwarf plant of good quality.

The objective of this investigation was to detect the response of sunflower plants to tank mix ratios and application methods of ancymidol, daminozide and ethephon for production of a dwarfed and picturesque specimen in an appropriate size. The results indicated that

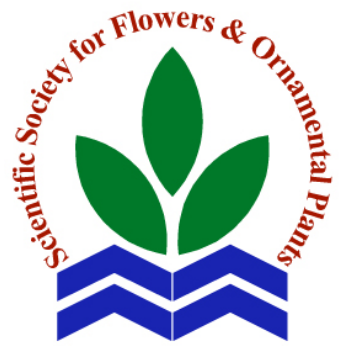

Scientific J. Flowers \& Ornamental Plants, 3(2):119-134 (2016).

Received: $1 / 6 / 2016$

Revised by: Prof. Dr. E.S. Nofal, Kafr El-Sheikh Univ.

Prof. Dr. A.Z. Sarhan, Cairo Univ. all the used combinations significantly decreased stem length of the treated plants. The shortest stems and internodes were obtained by ancymidol at either 5 or $20 \mathrm{ppm}$ (seed soaking) $+500 \mathrm{ppm}$ ethephon (spray). Stem diameter was increased by all combinations to reach the maximum by 5 ppm ancymidol (spray) +500 ppm ethephon (spray). The number of internode/stem was not greatly affected by the used combinations. However, the number of leaves/plant was significantly increased by all treatments. Also, all combinations caused a marked increment in the root length, with the superiority of $20 \mathrm{ppm}$ ancymidol (seed soaking) $+2450 \mathrm{ppm}$ daminozide (spray), which scored the longest roots in the two seasons. Spraying plants with $5 \mathrm{ppm}$ ancymidol $+250 \mathrm{ppm}$ ethephon or $20 \mathrm{ppm}$ ancymidol $+500 \mathrm{ppm}$ ethephons induced the greatest precocity in flower bud appearance and opening. Seed soaking in $20 \mathrm{ppm}$ ancymidol solution and spraying with $1250 \mathrm{ppm}$ daminozide reduced number of days from flower bud appearance to its opening . The mean number of lateral buds/stem, number of ray flowers/head and disc diameter were significantly improved, with few exceptions due to the different combinations than control plants in both seasons. Data, revealed that the highest content of chlorophyll a, b, carotenoids and total phenols were scored by spraying with either 5 or $20 \mathrm{ppm}$ ancymidol $+500 \mathrm{ppm}$ ethephon solutions. Total indoles and total soluble sugars were inconsistent and the percent of $\mathrm{N}$ was generally decreased. As for $\mathrm{P} \%$, it increased by most combinations, but $\mathrm{K} \%$ increased only by combining between ancymidol + ethephon.

Key words: Sunflowers, ancymidol, daminozide, ethephon, foliar spray. 


\section{Azza M. Abdel-Moniem}

\section{INTRODUCTION}

The annual sunflower plants (Helianthus annuus L., Fam. Asteraceae) are naturally tall, which is unsuitable for decoration of limited spaces. In order to facilitate their production in a protected environment and in the field, growth inhibitors can be utilized to reduce the size of these plants to make them suitable for commercial production as potplants. Plant growth retardants have been variously used in ornamental horticultural practice (Dewir et al., 2007). The plant growth retardants in ornamental horticulture are utilized commercially to produce compact, sturdy potted and bedding plants. This practice reduces the cost of pruning and allows obtaining a better ratio between vegetative growth and flower production, besides reducing the space in the greenhouse required for flower production thereby improving marketing quality (Marosz and Matysiak, 2005, Bekheta et al., 2008). In this concern, ancymidol had a beneficial effect in reducing plant height. Chistopher and Mark (1998) stated that an experiment was conducted on Mussaenda Queen Sirikit, where the profuse upright growth habit of some Mussaenda cultivars is undesirable for pot plant culture. Results revealed that the most attractive potted plants were produced with two drench applications of ancymidol at $0.5 \mathrm{mg} /$ pot. Higher concentrations or additional applications excessively reduced plant height. Kessler and Keever (2007) concluded that for producing a marketable greenhouse pot plant of Coreopsis verticillata $\mathrm{L}$. Moonbeam, pruned plant, in $10 \mathrm{~cm}$ pots received one application of ancymidol medium drenches at $0,2,4$, or 6 ppm as a linear decrease in shoot height, growth index and lateral shoot length were obtained with increasing rates of ancymidol. Maria et al. (2008) tested different concentration of daminozide on sunflower hybrid BRS Oasis (4,000, 6,000 and 8,000 $\mathrm{mgl}^{-1}$ ) applied at fifteen days after planting for the aim of the reduction in size of the plant. Results demonstrated that the size of the plants was smaller than that of the control. Therefore, for economical reasons, the use of $4000 \mathrm{mg} \mathrm{l}^{-1}$ of daminozide is suggested. Soner et al. (2010) on Chrysanthemum moriflolium cvs. Yellow Reagen and White Reagen showed that daminozide significantly affected days to flower, stem length, stem diameter and flower number per stem. The results suggested that ethephon could well be used to control the stem height and improve its ornamental value. Thiraporn et al. (2009) reported that aqueous solution of ethephon $(100 \mathrm{ml})$ at $0,100,300$ and $500 \mathrm{mg} \mathrm{l}^{-1}$ were fed twice after 6 weeks from planting at rhizomes of Curcuma alismetifolia Jajnep by drenching. The results emphasized that the application of ethephon decreased plant height, especially with application at $300 \mathrm{mg}$ $1^{-1}$ and $500 \mathrm{mg} \mathrm{l}^{-1}$. Application of ethephon also decreased the quality and quantity of flowers. At a high level of ethephon, flower stalk length and flower length were decreased. Furthermore, the number of pink and green bracts, and the number of flowers per a cluster of whole plant were decreased by ethephon application. Results indicated also that the highest concentration of ethephon $\left(500 \mathrm{mg} \mathrm{l}^{-1}\right)$ reduced the accumulation of plant nutrients in above ground part organs ( $\mathrm{N}, \mathrm{P}$ and $\mathrm{K})$ and in underground part organs ( $\mathrm{N}$ and $\mathrm{P})$.

The objective of this investigation was to detect the response of sunflower plants to tank mix ratios and application methods of ancymidol, daminozide and ethephon for production of a dwarfed and picturesque specimen in an appropriate size.

\section{MATERIALS AND METHODS}

The current work was undertaken at the nursery of Hort. Res. Inst., Giza, Egypt during 2014 and 2015 seasons in order to study the effect of some growth retardant combinations on growth performance, flowering and chemical composition of the annual sunflower plants, and to determine the most suitable combination for production of a dwarfed and picturesque specimen in an appropriate size. 
Seeds of annual sunflower (Helianthus annuus L. cv. Sunrich Orange Summer $981 \mathrm{~V})$, which is single-headed and has orange yellow ray florets with a black center were imported from abroad by Floramax local commercial farm, El-Mansouria, Giza, Egypt). They were sown on March, $30^{\text {th }}$ for each season in $25-\mathrm{cm}$ diameter plastic pots (one seed/pot) filled with about $5 \mathrm{~kg}$ of sand and clay soil mixture at equal parts by volume $(1: 1, \mathrm{v} / \mathrm{v})$. The physical and chemical properties of the sand and clay used in the two seasons are shown in Table (a).

Germination of the seeds was complete 6 days after sowing. Fifteen days after planting (on April, 15 ${ }^{\text {th }}$ ), when the plants showed two pairs of leaves, they were subjected to a tank mix with ancymidol (A-rest) at 5 or $20 \mathrm{ppm}$ concentration, applied either as soaking treatment where the seeds were soaked in the aforementioned growth retardant solutions for 30 minutes immediately before sowing, or as foliar spray till the solution was runoff, daminozide (B-Nine) at 1250 or 2450 ppm concentration as spray and ethephon at 250 or $500 \mathrm{ppm}$.

\section{Combined treatments were as follows:}

1- Control, as the plants were sprayed with tap water.

2- Ancymidol 5 ppm (spray) + daminozide at $1250 \mathrm{ppm}$ (spray).

3-Ancymidol 20 ppm 1 (spray) + daminozide at $1250 \mathrm{ppm}$ (spray).

4- Ancymidol 5 ppm (seed soaking) + daminozide at $1250 \mathrm{ppm}$ (spray).
5- Ancymidol $20 \mathrm{ppm}$ (seed soaking) + daminozide at $1250 \mathrm{ppm}$ (spray).

6- Ancymidol 5 ppm (spray) + daminozide at $2450 \mathrm{ppm}$ (spray).

7- Ancymidol 20 ppm (spray) + daminozide at $2450 \mathrm{ppm}$ (spray).

8- Ancymidol 5 ppm (seed soaking) + daminozide at $2450 \mathrm{ppm}$ (spray).

9- Ancymidol 20 ppm (seed soaking) + daminozide at $2450 \mathrm{ppm}$ (spray).

10-Ancymidol 5 ppm 1 (spray) + ethephon at 250 ppm (spray).

11- Ancymidol 20 ppm (spray) + ethephon at $250 \mathrm{ppm}$ (spray).

12- Ancymidol 5 ppm (seed soaking) + ethephon at $250 \mathrm{ppm}$ (spray).

13- Ancymidol 20 ppm (seed soaking) + ethephon at $250 \mathrm{ppm}$ (spray).

14- Ancymidol 5 ppm (spray) + ethephon at 500 ppm (spray).

15- Ancymidol $20 \mathrm{ppm}$ (spray) + ethephon at 500 ppm (spray).

16- Ancymidol 5 ppm (seed soaking) + ethephon at $500 \mathrm{ppm}$ (spray).

17- Ancymidol 20 ppm (seed soaking) + ethephon at $500 \mathrm{ppm}$ (spray).

The layout of the experiments was a complete randomized design with three replicates, as each replicate contained 5 plants Moreover, the regular agricultural practices needed for such plantation were carried out in time.

Table a. Physical and chemical properties of the used sand and clay in both seasons.

\begin{tabular}{|c|c|c|c|c|c|c|c|c|c|c|c|c|c|c|c|}
\hline \multirow{2}{*}{$\begin{array}{l}\text { Soil } \\
\text { type }\end{array}$} & \multirow{2}{*}{ 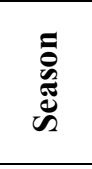 } & \multicolumn{4}{|c|}{$\begin{array}{c}\text { Particle size distribution } \\
(\%)\end{array}$} & \multirow{2}{*}{ S.P } & \multirow{2}{*}{$\begin{array}{c}\text { E.C. } \\
(\mathrm{ds} / \mathrm{m})\end{array}$} & \multirow{2}{*}{ pH } & \multicolumn{4}{|c|}{ Cations (meq/l) } & \multicolumn{3}{|c|}{ Anions (meq/l) } \\
\hline & & $\begin{array}{c}\text { Coarse } \\
\text { sand }\end{array}$ & $\begin{array}{l}\text { Fine } \\
\text { sand }\end{array}$ & It & Clay & & & & $a^{++}$ & $\mathbf{M g}^{++}$ & $\mathrm{Na}^{+}$ & $\mathbf{K}^{+}$ & 0-- & $\mathrm{Cl}^{-}$ & $\mathrm{SO}_{4}^{--}$ \\
\hline \multirow{2}{*}{$\begin{array}{l}\text { Sandy } \\
\text { soil }\end{array}$} & 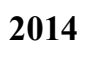 & 3 & 2.05 & 0.40 & 2 & 23.01 & 6 & 0 & 50 & 1.63 & 33.60 & 0.50 & 3.20 & 22.00 & 18.03 \\
\hline & 2015 & 84.76 & 6.29 & 1.50 & 7.45 & 21.87 & 3.71 & 7.80 & 19.42 & 8.33 & 7.20 & 0.75 & 1.60 & 7.80 & 26.30 \\
\hline \multirow{2}{*}{$\begin{array}{c}\text { Loamy } \\
\text { soil }\end{array}$} & 2014 & 10.18 & 46.17 & 19.53 & 24.12 & 35.00 & 3.48 & 8.27 & 17.50 & 9.42 & 20.00 & 0.79 & 3.80 & 10.00 & 33.91 \\
\hline & 2015 & 10.30 & 46.54 & 18.88 & 24.28 & 33.07 & 3.36 & 7.96 & 18.00 & 8.95 & 20.50 & 0.85 & 3.65 & 10.20 & 34.45 \\
\hline
\end{tabular}


Data recorded at the end of each season:

Plants in each treatment were observed daily until the first flower bud appeared:

- Stem length (cm)

- Stem diameter $(\mathrm{cm})$

- Number of internodes/stem

- Internode length (cm)

- Stem fresh and dry weights (g)

- Number of leaves/plant

- Leaf length and width $(\mathrm{cm})$

- Leaves fresh and dry weights (g)

- Root length (cm)

- Root fresh and dry weights (g)

- Number of days to flower bud appear once (days)

- Number of days to flower bud opening (days)

- Number of days from flower bud appear once to opening (days)

- Number of lateral buds/stem

- Flower head diameter $(\mathrm{cm})$

- Number of ray flowers per head

- Disc diameter $(\mathrm{cm})$

- Ray flower length (cm)

- Flower heads fresh and dry weight (g)

In fresh leaf samples, the photosynthetic pigments content (chlorophyll a, b and carotenoids), total phenols, total indoles and total soluble sugars were evaluated according to the methods of Yadava (1986), William et al. (1965), A.O.A.C. (1990) and Dubois et al. (1966), respectively, while in dry leaf ones, the percentages of nitrogen (Pregl, 1945), phosphorus (Luatanab and Olsen, 1965) and potassium (Jackson, 1973) were measured.

Data were tabulated and subjected to analysis of variance using program of SAS Institute (2009) and the differences among the means of treatments were determined with respect to their homogeneity by Duncan's New Multiple Range Test (Steel and Torrie, 1980) at 5\% level.

\section{RESULTS AND DISCUSSION \\ Effect of growth retardants combinations on:}

\section{1- Shoot and root growth parameters:}

Data presented in Table (1) exhibit that all combined treatments used in this study significantly decreased stem length of treated plants compared to the control ones in the two seasons. The shortest length was obtained by combining between $5 \mathrm{ppm}$ ancymidol soaking treatment and $500 \mathrm{ppm}$ ethephon spray one, which gave the least records at all in both seasons. The second position was occupied either by the combining between seed soaking in $20 \mathrm{ppm}$ ancymidol solution and spraying with ethephon at $500 \mathrm{ppm}$ level or between spraying with ancymidol at $5 \mathrm{ppm}$ and daminozide at $2450 \mathrm{ppm}$ recorded good shortening effect on stem length in both seasons. This may be due to the synergistic effect of ancymidol which inhibits GA production within plants and ethephon which is converted to ethylene in plant cells. This increased ethylene which causes cells to limit elongation or due to lumping the dwarfing effect of both ancymidol and daminozide in superssing stem elongation by blocking GA production at similar sites in the GA production process (Currey and Lopez, 2008),

The opposite was the right concerning the means of stem diameter which was increased by all combinations employed in such work with the superiority of spraying with 5 ppm ancymidol +500 ppm ethephon combined treatment that raised this parameter to $0.87 \mathrm{~cm}$ for the control plants in the two seasons versus 0.60 and $0.52 \mathrm{~cm}$ in the first and second seasons, respectively. In the second rank, came the combination of seed soaking in 20 ppm ancymidol solution+ 







\section{Azza M. Abdel-Moniem}

spraying with $2450 \mathrm{ppm}$ daminozide one, which increased means of such trait to 0.87 $\mathrm{cm}$ in the $1^{\text {st }}$ season and to $0.83 \mathrm{~cm}$ in the second one. In this connection, Currey and Lopez (2008) stated that plants take up ethephon through the leaves and converted it to ethylene in plant cells. The increased ethylene causes cells to limits elongation and increase in width instead. Moreover, Cuquel et al. (2010) found that control of sunflower height without decreasing stem diameter was obtained by applying daminozide twice at $6000 \mathrm{ppm}$ or daminozide three times at 4000 ppm.

Number of internodes/stem was not significantly affected by the used combinations. The least values were attained in both seasons by combining between seed soaking in $20 \mathrm{ppm}$ ancymidol and spraying with $1250 \mathrm{ppm}$ daminozide, while the highest ones were recorded by connecting between spraying with $5 \mathrm{ppm}$ ancymidol and 250 ppm ethephon. On the other side, internode length was generally decreased in response to the different applied treatments, to reach the shortest level by binding between soaking seeds in ancymidol solution at either 5 or $20 \mathrm{ppm}$ and spraying with ethephon at $500 \mathrm{ppm}$. This may be attributed to the observation that soaking method is more uniform and induce seeds to absorb more amount of active ingredient at lower concentrations than spraying method Currey and Lopez (2008).Stem fresh and dry weight fluctuated with non-significant differences compared to control plants in most cases of both seasons. However, the heaviest stem fresh weight was scored in the two seasons by a combination of seed soaking in $20 \mathrm{ppm}$ ancymidol + spraying with $250 \mathrm{ppm}$ ethephon; The heaviest stem dry weight was registered in the $1^{\text {st }}$ season by connecting between soaking the seeds in $20 \mathrm{ppm}$ ancymidol and $2450 \mathrm{ppm}$ daminozide spraying, and in the $2^{\text {nd }}$ one by conjuncting between spraying with ancymidol at $20 \mathrm{ppm}$ and daminozide at $1250 \mathrm{ppm}$. On the other hand, the lightest stem fresh and dry weights in both seasons were attained by soaking seeds in $20 \mathrm{ppm}$ ancymidol and spraying with $500 \mathrm{ppm}$ ethephon combined treatment, which gave the minimal records at all.

With regard to leaf parameters, data presented in Table (2) show that number of leaves/plant was significantly increased as a result of applying the different combinations, relative to control plants in most instances of both seasons. However, the excellency was for ancymidol either at $5 \mathrm{ppm}$ as spray or 20 ppm as soaking + ethephon spray at 250 ppm, as well as seed soaking in 5 ppm ancymidol solution + ethephon spray at 500 ppm combined treatments, which gave the highest averages in both seasons. The opposite was the right regarding leaf length, that was slightly decreased with nonsignificant differences compared to control plants in the two seasons, except for combining between soaking seeds in ancymidol at 5 or $20 \mathrm{ppm}$ and spraying with daminozide at $2450 \mathrm{ppm}$ treatment that elevated this character to the utmost height compared to control plants in the $1^{\text {st }}$ and $2^{\text {nd }}$ seasons. On the other side, leaf width and leaves fresh and dry weights were unsteady in response to the various used combinations in the two seasons. However, the widest leaves and heaviest fresh and dry weights were obtained in both seasons by connecting between seed soaking either in 5 or 20 ppm ancymidol solution and spraying with 2450 ppm daminozide one, while leaves having the lightest fresh and dry weights were attained in the two seasons by a combination of seed soaking in $5 \mathrm{ppm}$ ancymidol + spraying with 500 ppm ethephon.

A similar trend was also observed regarding root parameters as illustrated in Table (3), where all combinations induced a marked increment in the root length of treated plants, with the mastership of seed soaking in 20 ppm ancymidol solution + spraying with $2450 \mathrm{ppm}$ daminozide combined treatment, which registered the longest root in both seasons. The means of fresh and dry weights were inconsistent. The greatest records were recorded in the two seasons by a combination of $20 \mathrm{ppm}$ ancymidol soaking $+250 \mathrm{ppm}$ ethephon spray. 





Azza M. Abdel-Moniem

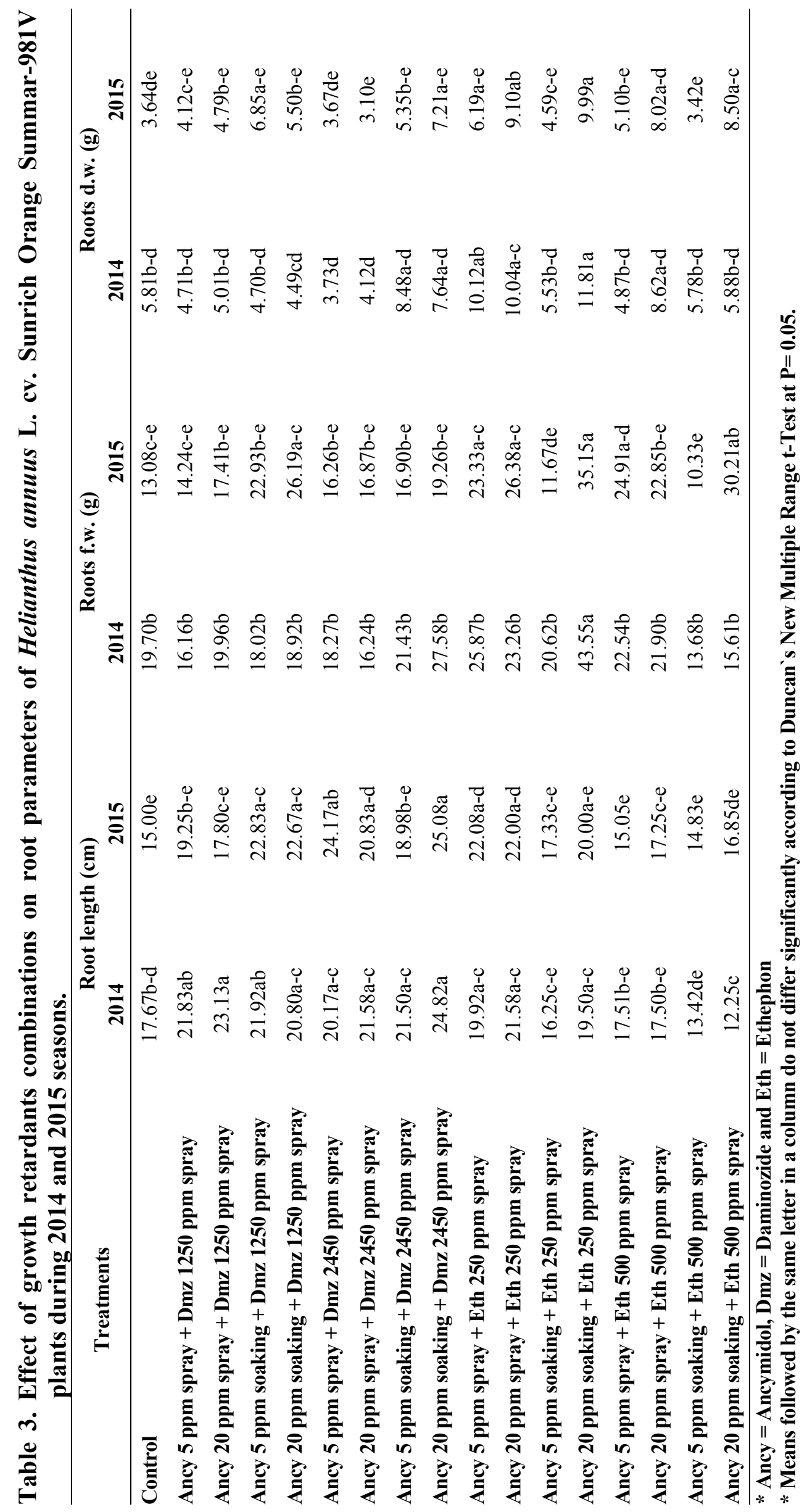


The variable effects of the used combinations on vegetative and root growth parameters is reasonable because of the difference in application method, type of growth retardant used and their concentration.

However, these effects were documented by Whipker and McCall (2000), Pallez et al. (2002), Whipker et al. (2004), Wanderley et al. (2007) and Giuffrida et al. (2009) on sunflower, and Kessler and Keever (2007) on "Moonbeam" coreopsis.

\section{2- Flowering parameters:}

According to data listed in Table (4), it can be concluded that the least number of days to either flower bud appearance or to its opening (day) was recorded in both seasons by either spraying with $5 \mathrm{ppm}$ ancymidol + $250 \mathrm{ppm}$ ethephon or spraying with $20 \mathrm{ppm}$ ancymidol +500 ppm ethephon combined treatments, which caused precocity in these two traits by about 3 days or more with significant differences compared to control in both seasons. The other treatments however induced a slight earliness with few exceptions, in such two characters with nonsignificant differences when compared to the control plants. On the other hand, the highest number of days to flower bud appearance and opening was due to a combination of soaking with $20 \mathrm{ppm}$ ancymidol $+250 \mathrm{ppm}$ ethephon solutions. In general, all combined treatments caused an increment in the number of days from flower bud appearance to its opening, especially when connecting between spraying with $5 \mathrm{ppm}$ ancymidol + $500 \mathrm{ppm}$ ethephon solutions, while the least records in this criterion was achieved in the two seasons by combining between seed soaking in $20 \mathrm{ppm}$ ancymidol solution and spraying with 1250 daminozide one. This is reasonable because the new formed metabolites in the dwarfed plants are usually used for forcing rather than growth. In this concern, Kofidis et al. (2008) mentioned that prohexadione-Ca at $20 \mathrm{ppm}$ induced precocious flowering in coriander plants (3-5 days earlier). Kessler and Keever (2007) postulated that number of days from treatment to first flower open in "Moonbeam" Coreopsis plants increased linearly with increasing daminozide rate.On the contrary Warner and Erwin (2003) stated that daminozide at 2500 and $5000 \mathrm{ppm}$ did not delay flowering of Hibiscus trionum plants.

In addition, the mean number of lateral buds/stem (Table, 5) was improved generally by most combinations with the superiority of spraying with either 5 ppm ancymidol +500 ppm ethephon or 50 ppm ancymidol +250 ppm ethephon in the first season, and a combination of seed soaking in $5 \mathrm{ppm}$ ancymidol solution + foliar spray with 500 ppm ethephon solution in the second one. This may indicate to the role of ethephon in reducing the apical dominance which can increase axillary budding and branching (Currey and Lopez, 2008). The opposite was the right regarding flower head diameter which was reduced as a result of applying most combined treatments, with nonsignificant differences in most instances of both seasons compared to control plants. However, the smallest diameter was recorded by the combination of $5 \mathrm{ppm}$ ancymidol (spray) $+500 \mathrm{ppm}$ ethephon (spray), followed by $5 \mathrm{ppm}$ ancymidol (soaking) $+500 \mathrm{ppm}$ ethephon (spray), and by $20 \mathrm{ppm}$ ancymidol (spray) $+500 \mathrm{ppm}$ ethephon (spray). The widest flower head was attained in the first season by soaking with $20 \mathrm{ppm}$ ancymidol $+250 \mathrm{ppm}$ ethephon solutions combined treatment and in the second season by 5 ppm ancymidol (soaking) $+2450 \mathrm{ppm}$ daminozide (spray) combined treatment.

Contrary to results of flower head diameter, data presented in Table (5) cleared that number of ray flowers/head and disc diameter were increased with various significance levels relative to the control plants in the two seasons, with the mastery of both $20 \mathrm{ppm}$ ancymidol (soaking) +250 ppm ethephon (spray) and $20 \mathrm{ppm}$ ancymidol (spray) +500 ppm ethephon (spray) combined treatments that gave the highest averages in these two parameters 
Azza M. Abdel-Moniem

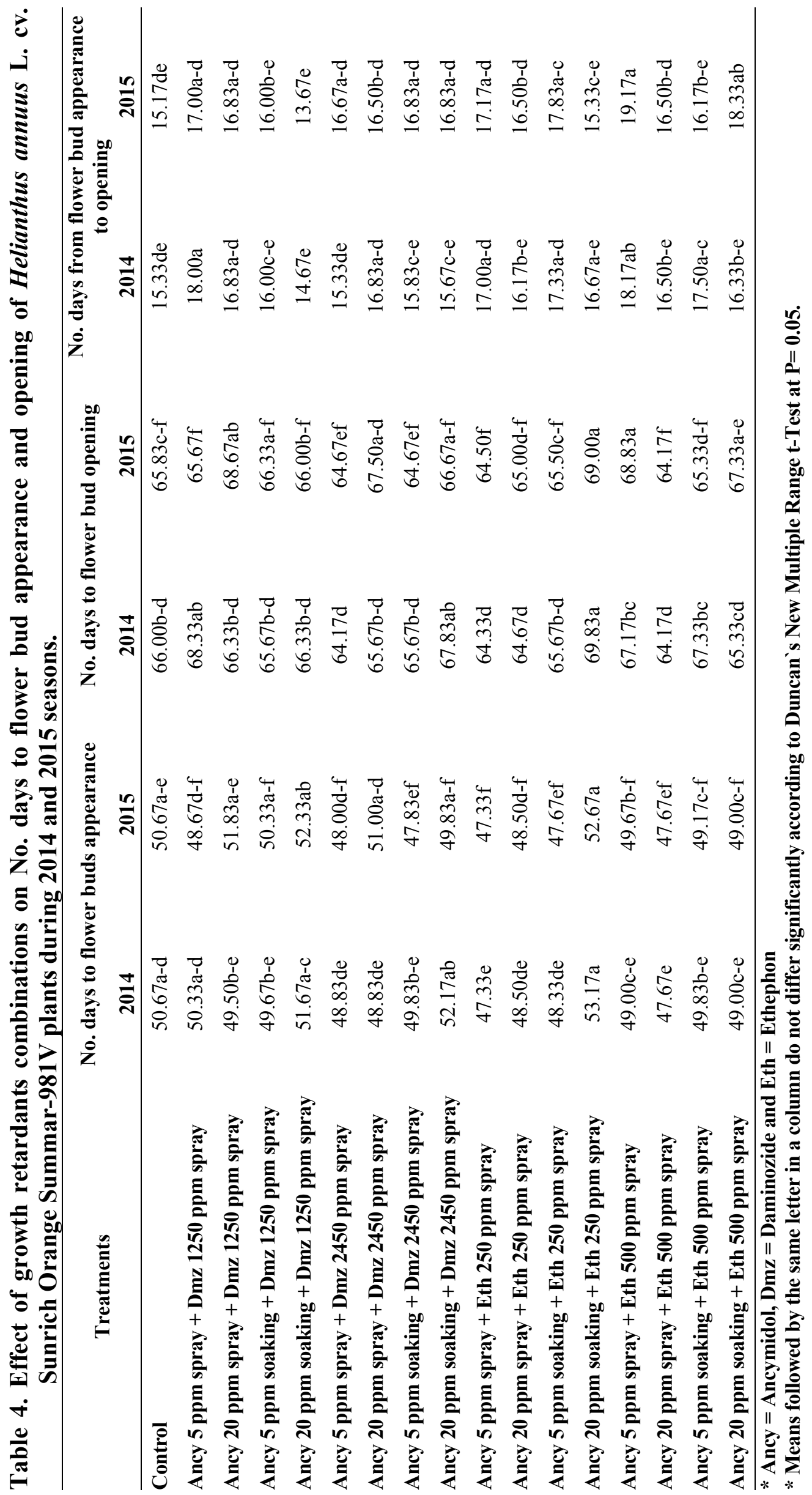




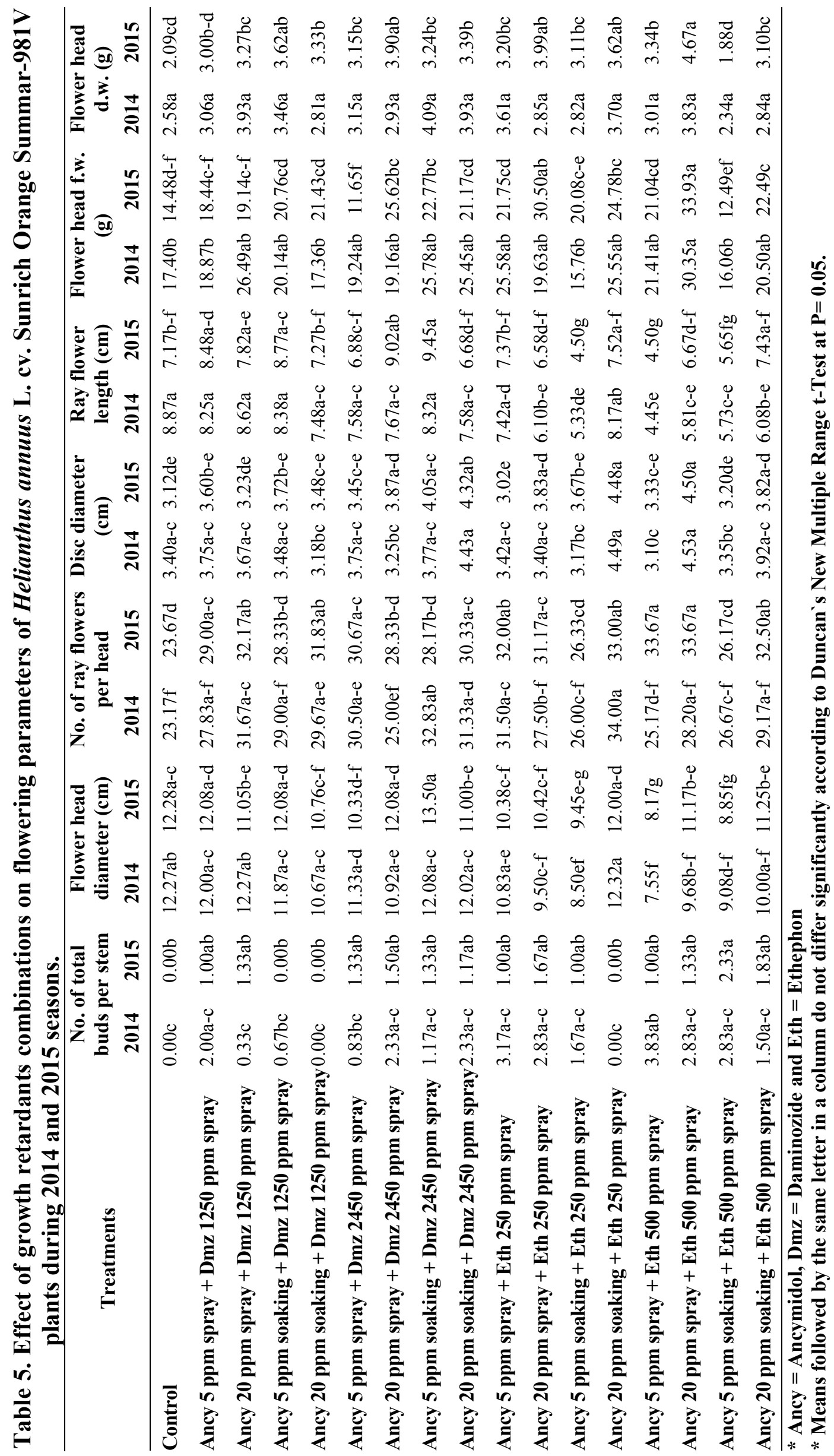


over control plants and all other combinations. The binding between ancymidol and daminozide at different concentrations and application methods had no clear effect on ray flower length, while conneting between ancymidol and ethephon caused a linear decrement in this trait with increasing concentration of either of the two chemicals, to reach the minimum by a combination of 5 ppm ancymidol (spray) + $500 \mathrm{ppm}$ ethephon (spray) in the two seasons. On the other hand, flower head fresh and dry weights were improved by the various combinations used in this study, with the prevalence of spraying with $20 \mathrm{ppm}$ ancymidol +500 ppm ethephon solutions which recorded the heaviest fresh and dry weights of flower heads in the two seasons.

Similar observations to the previous ones were detected by Whipker et al. (2004) and Giuffrida et al. (2009) on some cultivars of sunflower. In this concern, Krause et al. (2003) indicated that daminozide at either $1275 \mathrm{ppm}$ (drench) $+1275 \mathrm{ppm}$ (spray) or $1275 \mathrm{ppm}$ (drench) $+2550 \mathrm{ppm}$ (spray) significantly increased number of flower buds and number of flowers/inflorescence in treated plants of Petunia hybrida "Bravo Pink".

\section{3- Chemical composition of the leaves:}

It is obvious from data registered in Table (6) that content of chlorophyll a, b and carotenoids increased slightly in the leaves of treated plants with few exceptions as compared to the same contents in control leaves. The highest content of these pigments was related to spraying with either 5 or 20 ppm ancymidol +500 ppm ethephon combined treatments. The least content was recorded by connecting between spray with 5 ppm ancymidol +1250 ppm daminozide solutions.

Table 6. Effect of growth retardants combinations on pigments, total phenols and total indoles content in the leaves of Helianthus annuus L. cv. Sunrich Orange Summar-981V plants during 2015 season.

\begin{tabular}{|c|c|c|c|c|c|}
\hline Treatments & $\begin{array}{c}\text { Pigmen } \\
\text { Chlorophyll } \\
\text { (A) }\end{array}$ & $\begin{array}{l}\text { its content (m) } \\
\text { Chlorophyll } \\
\text { (B) }\end{array}$ & $\begin{array}{l}\text { g/g f.w.) } \\
\text { Carotenoids }\end{array}$ & $\begin{array}{c}\text { Total } \\
\text { phenols } \\
\text { (ppm) }\end{array}$ & $\begin{array}{c}\text { Total } \\
\text { indoles } \\
\text { (ppm) }\end{array}$ \\
\hline Control & 1.19 & 0.41 & 0.24 & 0.19 & 0.08 \\
\hline Ancy 5 ppm spray + Dmz 1250 ppm spray & 0.76 & 0.20 & 0.18 & 0.29 & 0.05 \\
\hline Ancy 20 ppm spray + Dmz 1250 ppm spray & 1.22 & 0.36 & 0.25 & 0.26 & 0.07 \\
\hline Ancy 5 ppm soaking + Dmz 1250 ppm spray & 1.30 & 0.52 & 0.21 & 0.28 & 0.08 \\
\hline Ancy 20 ppm soaking + Dmz 1250 ppm spray & 1.39 & 0.48 & 0.18 & 0.28 & 0.12 \\
\hline Ancy 5 ppm spray + Dmz 2450 ppm spray & 0.96 & 0.29 & 0.23 & 0.26 & 0.07 \\
\hline Ancy 20 ppm spray + Dmz 2450 ppm spray & 1.45 & 0.34 & 0.23 & 0.27 & 0.09 \\
\hline Ancy 5 ppm soaking + Dmz 2450 ppm spray & 1.34 & 0.46 & 0.24 & 0.26 & 0.10 \\
\hline Ancy 20 ppm soaking + Dmz 2450 ppm spray & 1.35 & 0.46 & 0.23 & 0.35 & 0.06 \\
\hline Ancy 5 ppm spray + Eth 250 ppm spray & 1.35 & 0.47 & 0.21 & 0.18 & 0.09 \\
\hline Ancy 20 ppm spray + Eth 250 ppm spray & 1.41 & 0.44 & 0.24 & 0.15 & 0.01 \\
\hline Ancy 5 ppm soaking + Eth 250 ppm spray & 1.38 & 0.45 & 0.27 & 0.31 & 0.12 \\
\hline Ancy 20 ppm soaking + Eth 250 ppm spray & 1.12 & 0.41 & 0.29 & 0.29 & 0.07 \\
\hline Ancy 5 ppm spray + Eth 500 ppm spray & 1.50 & 0.51 & 0.29 & 0.17 & 0.08 \\
\hline Ancy 20 ppm spray + Eth 500 ppm spray & 1.47 & 0.54 & 0.26 & 0.23 & 0.04 \\
\hline Ancy 5 ppm soaking + Eth 500 ppm spray & 1.35 & 0.35 & 0.22 & 0.21 & 0.07 \\
\hline Ancy 20 ppm soaking + Eth 500 ppm spray & 1.42 & 0.47 & 0.17 & 0.25 & 0.08 \\
\hline
\end{tabular}

* Ancy = Ancymidol, Dmz = Daminozide and Eth = Ethephon 
In general, all the applied combinations induced a marked increment in total phenols content, especially the combinations of 20 ppm ancymidol (soaking) $+2450 \mathrm{ppm}$ daminozide (spray). On the other side, content of total indoles was changeful. The minimal content $(0.01 \mathrm{ppm})$ was due to spraying with $20 \mathrm{ppm}$ ancymidol $+250 \mathrm{ppm}$ ethephon solutions, whereas the maximal one was scored by combining either between 20 ppm ancymidol (soaking) and $1250 \mathrm{ppm}$ daminozide (spraying) or between $5 \mathrm{ppm}$ ancymidol (soaking) and $250 \mathrm{ppm}$ ethephon (spraying) treatments. In contradiction to the current observations, Kazaz et al. (2010) reported that chlorophyll $\mathrm{a}$ and $\mathrm{b}$ contents were unaffected by the sole application of daminozide, while Kofidis et al. (2008) revealed that coriander plants treated with $500 \mathrm{ppm}$ daminozide had dark green leaves with $16 \%$ more chlorophyll than the control leaves, and those treated with $1000 \mathrm{ppm}$ daminozide had leaves with $13 \%$ less chlorophyll than the controls.

It can be shown from data presented in Table (7) that the percent of total soluble sugars was unsteady in the leaves of treated plants. The highest percent was gained by combining either between $20 \mathrm{ppm}$ ancymidol (spray) and 2450 daminozide (spray) or between $5 \mathrm{ppm}$ ancymidol (soaking) and $2450 \mathrm{ppm}$ daminozide (spray), as these two combinations raised this concentration to 3.01 and $3.00 \%$ vs. $1.23 \%$ for control plants, respectively. The nitrogen $\%$ was generally decreased in response to the different used combinations with the exception of $5 \mathrm{ppm}$ ancymidol (spray) $+2450 \mathrm{ppm}$ daminozide (spray) combined treatment that caused a slight rising in $\mathrm{N} \%$. The percent of phosphorus was increased by the applied combinations with few exceptions. The highest $\mathrm{P} \%$ was achieved by binding between ancymidol at either 5 or $20 \mathrm{ppm}$ (spray) and $250 \mathrm{ppm}$ ethephon (spray). As for potassium percentage, it was improved by only combining between ancymidol treatments and ethephon ones, with the excellency of 5 ppm ancymidol (soaking) + $500 \mathrm{ppm}$ ethephon (spray) combination that increased this element to $1.96 \%$ versus $1.76 \%$ for the control.

Increasing content of some constituents and decreasing content of some others is reasonable due to variance of type of the chemicals used and their concentrations, beside the difference of application method. In this regard, Khuankaew et al. (2009) observed that application of ethephon at 500 ppm gave the lowest of N, P and K contents in aboveground organs of curcuma plants, and similarly, $\mathrm{N}$ and $\mathrm{P}$ contents in underground organs. Amount of $\mathrm{K}$ in both organs is higher than the amount of $\mathrm{N}$ and $\mathrm{P}$. The accumulation of $\mathrm{K}$ in aboveground part is higher than in underground one.

According to findings mentioned above, it is advised to treat "Sunrich Orange Summar-981V" sunflower plants grown in 25-cm-diameter plastic pots with ancymidol at either 5 or $20 \mathrm{ppm}$ concentration as seed soaking for $30 \mathrm{~min}$. plus spraying the foliage with $500 \mathrm{ppm}$ ethephon solution for 3 times with 2 weeks interval to get small-sized stunted plants with proper number of leaves and flower heads full of ray florets.

\section{RECOMMENDATION}

From the results, it is recommended to treat sunflower cv. Sunrich Orange Summer $981 \mathrm{~V}$ plants with ancymidol at either 5 or 20 ppm level as seed soaking for $30 \mathrm{~min}+$ spraying the foliage with $500 \mathrm{ppm}$ ethephon solution for 3 times with 2 weeks interval to obtain small-sized pot-plants carrying proper number of natural-sized leaves and flower heads full of ray florets.

\section{REFERENCES}

A.O.A.C. (1990). Association of Official Agricultural Chemists "Official Methods of Analysis of the Association of Official Agricultural Chemists". $15^{\text {th }}$ Ed., Arlington, Virginia 22201:877-878. 
Table 7. Effect of growth retardants combinations on total soluble sugars, $N, P$ and $K$ in the leaves of Helianthus annuus L. cv. Sunrich Orange Summar-981V plants during 2015 season.

\begin{tabular}{lcccc}
\hline \multicolumn{1}{c}{ Treatments } & $\begin{array}{c}\text { Total soluble } \\
\text { sugars (\%) }\end{array}$ & N (\%) & P (\%) & K (\%) \\
\hline Control & 1.23 & 1.75 & 0.39 & 1.76 \\
Ancy 5 ppm spray + Dmz 1250 ppm spray & 1.12 & 1.37 & 0.58 & 1.20 \\
Ancy 20 ppm spray + Dmz 1250 ppm spray & 1.42 & 1.50 & 0.42 & 1.39 \\
Ancy 5 ppm soaking + Dmz 1250 ppm spray & 1.01 & 0.82 & 0.46 & 1.61 \\
Ancy 20 ppm soaking + Dmz 1250 ppm spray & 0.89 & 1.15 & 0.57 & 1.59 \\
Ancy 5 ppm spray + Dmz 2450 ppm spray & 1.36 & 1.86 & 0.33 & 1.42 \\
Ancy 20 ppm spray + Dmz 2450 ppm spray & 3.01 & 1.37 & 0.33 & 1.07 \\
Ancy 5 ppm soaking + Dmz 2450 ppm spray & 3.00 & 1.30 & 0.39 & 1.32 \\
Ancy 20 ppm soaking + Dmz 2450 ppm spray & 1.42 & 1.27 & 0.13 & 1.43 \\
Ancy 5 ppm spray + Eth 250 ppm spray & 0.99 & 1.63 & 0.70 & 1.83 \\
Ancy 20 ppm spray + Eth 250 ppm spray & 1.07 & 1.43 & 0.73 & 1.54 \\
Ancy 5 ppm soaking + Eth 250 ppm spray & 1.21 & 1.04 & 0.52 & 1.85 \\
Ancy 20 ppm soaking + Eth 250 ppm spray & 2.35 & 1.58 & 0.56 & 1.83 \\
Ancy 5 ppm spray + Eth 500 ppm spray & 1.20 & 1.38 & 0.66 & 1.18 \\
Ancy 20 ppm spray + Eth 500 ppm spray & 1.40 & 1.28 & 0.59 & 1.23 \\
Ancy 5 ppm soaking + Eth 500 ppm spray & 1.13 & 1.30 & 0.54 & 1.96 \\
Ancy 20 ppm soaking + Eth 500 ppm spray & 1.53 & 1.41 & 0.51 & 1.83 \\
\hline
\end{tabular}

* Ancy $=$ Ancymidol, Dmz $=$ Daminozide and Eth $=$ Ethephon

Bekheta, M.M.; Abbas, S.; El-Kobisy, O.S. and Mahgoub, M.H. (2008). Influence of selenium and paclobutrazol on growth, metabolic activites and anatomical characters of Gerbera jasmonii L. Aust. J. Basic Applied Sci., 2:1284-1297.

Chistopher, S.C. and Mark, P.B. (1998). Growth regulator effects on plant height of potted Mussaenda 'Queen Sirikit'. Hortscience, 33(1):178-181.

Cuquel, F.L.; Sabbagh, Maria C. and Barneche de Oliveira, Ana, C. (2010). Control of ornamental sunflower height with daminozide. Semina: Ciencias Agrarias, Londrina, 31(1):1187-1192.

Currey, C.J. and Lopez, R.G. (2008). Applying plant growth retardants for height control. Purdue Dept. Hort. and Landscape Archit., www.Hort.Purdue.edu.

Dewir, Y.H.; Chakrabarty, D.; Ali, M.B.; Singh, N.; Hahn, E. and Paek, K. (2007). Influence of $\mathrm{GA}_{3}$, sucrose and solid medium/biorenctor culture on in vitro flowering of Spathiphyllum and association of glutathione metabolism. Plant Cell Tissue and Organ Cult., 90(3):225-235.

Dubois, M.; Smith, F.; Gilles, K.A.; Hamilton, J.K. and Rebers, P.A. (1966). Colorimetric method for determination of sugars and related substances. Ann. Chem., 28(3):350-356.

Giuffrida, F; Cassaniti, C. and Leonardi, C. (2009). Effects of cultivation practices on 
sunflower production as cut flower. Acta Hort., 807(2):699-704.

Jackson, M.L. (1973). Soil Chemical Analysis. Prentice Hall of India Private Limited M-97, New Delhi, India, 498 pp.

Kazaz, S.; Askin, M.A.; Kilic, S. and Ersoy, N. (2010). Effects of day length and daminozide on the flowering of some quality parameters and chlorophyll content of Chrysanthemum morifolium Ranat. Sci. Res. And Essays, 5(21):32813288.

Kessler, J.R. and Keever, G.J. (2007). Plant growth retardants affect growth and flowering of Coreopsis verticillata "Moonbeam". J. Envirn. Hort., 25(4):229-233.

Khuankaew, T.; Ohyama, T. and Ruamrungsri, S. (2009). Effects of ethephon application on growth and development of Curcuma alismatifolia Gagnep. Bull. Fac. Agric. Nligata Univ., 62(1):9-15.

Kofidis, G.; Giannakoula, A. and Ilias, I.F. (2008). Growth, anatomy and chlorophyll fluorscence of coriander plants (Coriandrum sativun L.) treated with prohexadione-calcium and daminozide. Acta Biologica Cracoviensia, 50(2):5562.

Krause, J.; Krystyniak, E. and Schroeter, A. (2003). Effect of daminozide on growth and flowering of bedding plants. J. Fruit and Ornam. Plant Res., 11:107-112.

Luatanab, F.S. and Olsen, S.R. (1965). Test of an ascorbic acid method for determining phosphorus in water and $\mathrm{NaHCO}_{3}$ extracts from soil. Soil Sci. Soc. Amer. Proc., 29:677-678.

Maria, C.S.; Cuquel, F.L.; Barneche de Oliveria, Ana C. and Edson, P.G. (2008). Size reduction of ornamental sunflowers by application of daminozide. Proc $.17^{\text {th }}$ International Flower Conference, Cordoba, Spain, p: 305-307.
Marosz, A. and Matysiak, B. (2005). Influence of growth retardants on growth and flower bud formation in Rhododendron and Azalea. Dendrobiology, 54:35-40.

Pallez, L.C.; Dole, J.M. and Whipker, B.E. (2002). Production and postproduction studies with potted sunflowers. HortTechnology, 12(2):206-210.

Pregl, F. (1945). Quantitative Organic Micro-Analysis, $4^{\text {th }}$ Ed., J \& A., Churchill, Ltd., London, p: 203-209.

SAS Institute (2009). SAS/STAT User's Guides Statistics. Vers. 6.04, $4^{\text {th }}$ Ed., SAS Institute Inc., Cary, N.C., USA.

Soner, K.M.; Atilla, A.; Kilic, S. and Ersoy, N. (2010). Effect of day length and daminozide on the flowering, some quality parameters and chlorophyll content of Chrysanthemum morifolium Ramat. Scientific Research and Essays, 5(21):3281-3288.

Steel, R.G.D. and Torrie, J.H. (1980). Principles and Procedures of Statistics. McGrow Hill Book Co., Inc., New York, p: 377-400.

Thiraporn, K.; Ohyama, T. and Ruamrungsri, S. (2009). Effects of ethephon application on growth and development of Curcuma alismatifolia Gagnep. Nigata Univ. Agri. Department Research Report Chapter 62:1.

Wanderley, C.S.; Rezende, R. and Andrade, C.A. (2007). Efeito de Paclobutrazol como regulador de crescimento $\mathrm{e}$ producao de flores de girassol em cultivo. Ciencia Agrotechnologia, Lavars, 31(6):1672-1678.

Warner, R. M. and Erwin, J. E. (2003). Effect of plant growth retardants on stem elongation of Hibiscus species. HortTech., 13(2):293-296.

Whipker, B.E. and McCall, I. (2000). Response of potted sunflower cultivars to daminozide foliar sprays and 


\title{
Azza M. Abdel-Moniem
}

paclobutrazol drenches. HortTechnology, 10(1):209-211.

Whipker, B.E.; McCall, I.; Gibson, J.L. and Cavins, T.J. (2004). Flurprimidol foliar sprays and substrate drenches control growth of "Pacino" pot sunflowers. HortTechnology, 14(3):411-414.

William, M.; Chichlilo, P.; Clifford, P. A. and Reynolds, M. (1965). Official
Methods of Analysis of the Association of Official Agriculture Chemists, $10^{\text {th }}$ Ed., Washington D.C. 20044:52-55.

Yadava, Y.L. (1986). Rapid and nondestructive methods to determine chlorophyll in intact leaves. HortScience, 21:1449-1450.

\section{تأثير بعض مثبطات النمو على نمو وإزهار نباتات عباد الثمس (صنف Sunrich Orange" Summer $981 \mathrm{~V}$ ) ب- إضافة الإنسيميدول، الدامينوزيد، والإيثيفون فى توليفات}

\author{
عزة محمد عبد المنعم \\ قسم بحوث الزينة وتنسيق الحدائق، معهد بحوث البساتين، مركز البحوث الزر اعية، الجيزة، مصر.
}

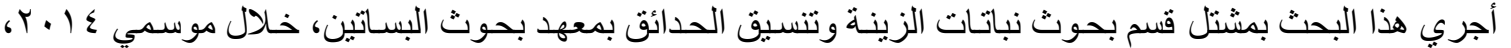

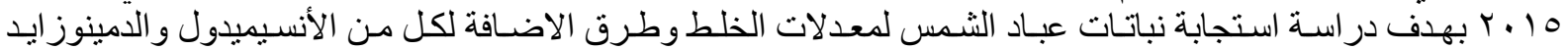

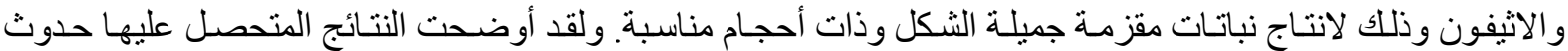

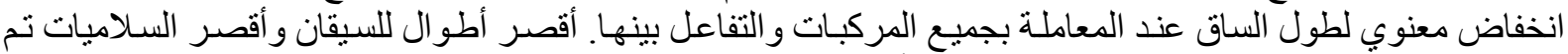

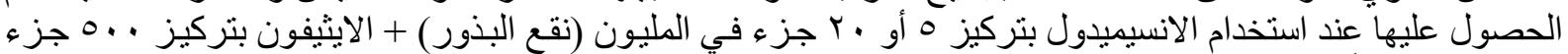

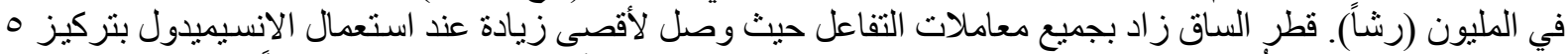

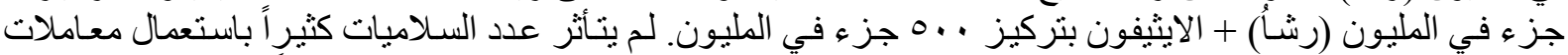

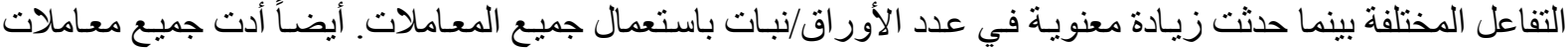

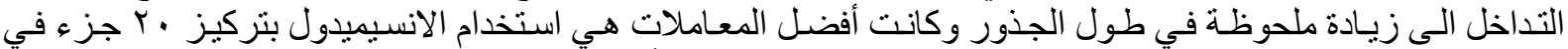

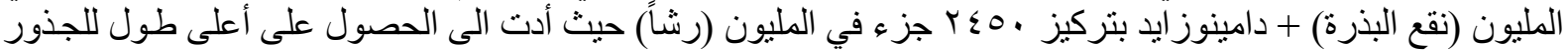
خلال موسمي الدر اسة.

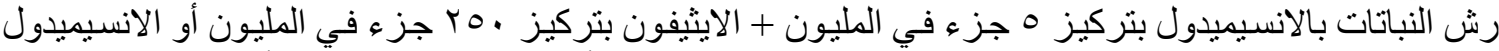

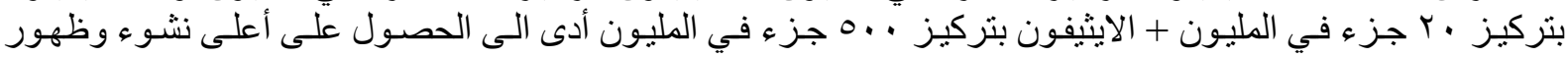

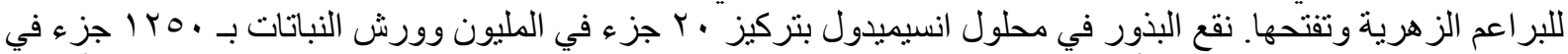

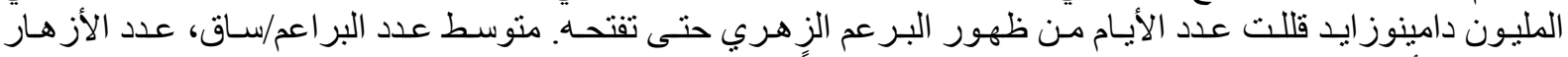

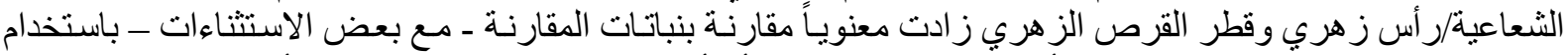

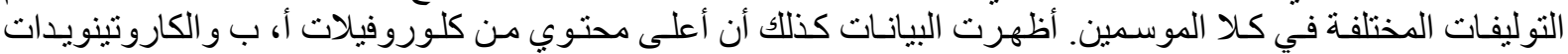

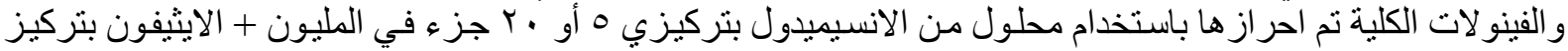

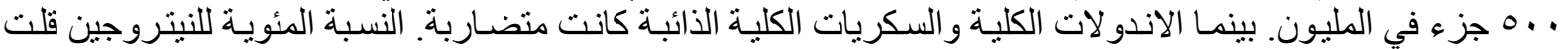

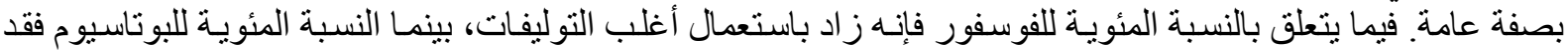
ز زادت باستعمال التوليفات بين الانسيميدول + الايثيفون فقط. 